\title{
Airport Passenger Traffic Forecast: An Exploratory Study
}

\author{
Pintanugra Persadanta \\ Institut Transpotasi dan Logistik Trisakti \\ E-mail: pintanugra@itltrisakti.ac.id
}

\begin{abstract}
Sultan Hasanuddin International Airport has been an important hub airport in Indonesia for decades, connecting traffic between west and east Indonesia as well as functioned as international gate in East Indonesia along with Sam Ratulangi Airport. Analysing characteristics of historical traffic data pattern, determining factors affecting past behaviour and building the best-fit model to forecast future traffic are critical for airport operator. Several forecast techniques are employed including Holt-Winter, Decomposition Method and Econometric Model. Moreover, trend, seasonal event and irregular phenomena from past data are observed to analyse traffic behaviour. Passenger traffic data from 1995 up to 2015 is utilized to predict future traffic until 2020. Validation of selected forecast model is conducted by implementing backtesting method which shows that the model successful foretell annual passenger movement with estimation average deviation around $0.5 \%$. Some potential risks and opportunities as well as potential route expansion are identified to fortify future challenges.
\end{abstract}

Keywords: Holt-Winter, Decomposition Method, Econometric Model, Data Behaviour Analysis, Backtesting Method.

\section{INTRODUCTION}

Indonesia is a country with 17,000 islands including five major islands. Therefore connectivity is a main transport issue. Air and sea transport are vital transport mode to connect those islands whilst land transport cannot. Air transport is a favourable transport mode particularly for person and perishable goods to travel from west to east of Indonesia. As shown in Figure1, there are 270 airports in which 29 are international airports (MoT, 2013).

The objectives of this paper are to analyse characteristics of historical traffic data pattern, determine factors affecting past behaviour and build the best-fit model to forecast future traffic from a selected airport. Furthermore this paper examines unserved destination points to be served through the selected airport in order to expand its market.
The airport selected is Sultan Hasanuddin International Airport (UPG) in Indonesia.

The research scope is the air transport demand at UPG which is the passenger traffic including domestic and international passenger (to and from UPG) and passenger transit through UPG.

\section{METHODS}

This paper starts with describing the market of the airport, traffic characteristics, and potential factors which influence passenger traffic. The observed key factors then used to develop best-fit forecasting model for short and medium-term period. Seasonal events, traffic trend and irregular events are investigated for short term forecast with an assumption that similar phenomena will continue in the following year. For mediumterm forecast, determinant factors affecting the 
past traffic pattern will be identified in a causal model. It is believed similar factors will affect the future traffic behaviour pattern.

\section{Demographic Factors}

Huge population is one of the important demand drivers of air transport in Indonesia. In 2014 , the population was amounted to around 255 million but the air passengers carried was only 94 million (World Bank, 2016). Taking into account that one people fly more than once a year or took return flights, there is a great opportunity for air transport to grow in the future.

\section{Economic Performance}

Currently, Indonesia is the largest economy in ASEAN and the $16^{\text {th }}$ largest in the world in term of GDP (World Bank, 2015a). Asian Development Bank (2015) stated that Indonesia has successfully reduced the prevalence of poverty and showed strong economic growth over the past 6 years. Strong economic performance will stimulate people's ability and willingness to use air transport. Also, GDP is strong related to air transport demand (Suryan, 2017)

\section{Low Cost Airlines}

Indonesia air transport has gain much benefit from the performance of low cost airlines such as Lion Air Indonesia which ordered more than 400 aircrafts from Boeing and Airbus (Airbus, 2013; Boeing, 2011). UPG is the third Lion's largest hub in addition to Soekarno-Hatta International Airport and Juanda International Airport. Lion Air is important for UPG because from total 326,209 seats/week available at UPG around 189,553 seat/week comes from Lion Air (CAPA, 2016).

\section{Backtesting Method}

Firstly applied in financial sector, backtesting or risk model evaluation is an important step of the internal model's approach to risk management. It analyses the violation of ex-ante Value-at-Risk (VaR) parameter and assesses the viability of selected model by using historical data (Christoffersen, 2003).

\section{RESULT AND DISCUSSIONS}

UPG in Makassar plays role as the primary hub airport in the eastern part whilst Soekarno-Hatta Airport in Jakarta plays role as the primary hub airport in the west part of Indonesia (MoT, 2013). Currently UPG served 9.7 million passengers; around one-fourth or 2.2 million is transit passenger (AP I, 2016). The airport takes much advantage from connecting flights as shown in Figure 1.

In 2008, UPG redeveloped their terminal with capacity 7 million passengers annually. Following the increase of air transport demand, the airport operator announced to expand the terminal capacity to 12 million passengers (Flightglobal, 2014). Moreover, the airport has built a new runway with length $3,500 \mathrm{~m}$ in 2010 to support their performance.

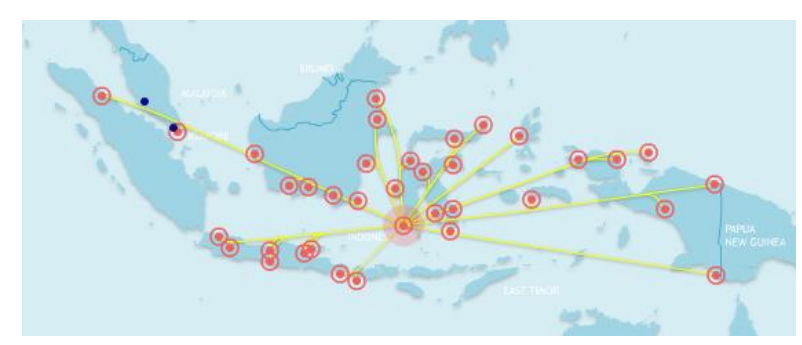

Figure 1. UPG Schedule Flight Routes

\section{UPG Historical Data Analysis}

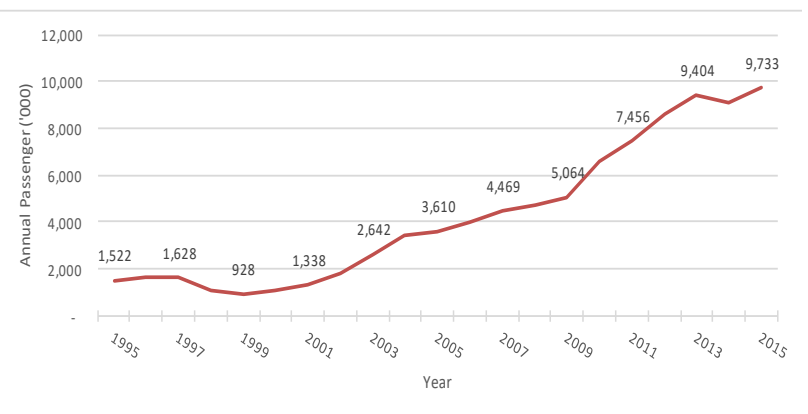

Figure 3. UPG Passenger Traffic 1995 - 2015

Annual passenger at UPG has grown significantly from 1.5 million in 1995 to 9.7 million in 2015 as shown in Figure 2. In 1998 Indonesia suffered economic recession and political reformation which then weakened the individual's purchasing power. This condition affected air traffic at UPG. In 1999 government has deregulated aviation policy to help airlines survive during economic recession (Saraswati and Hanaoka, 2013). Deregulation has stimulated the opening of 
several new airlines especially low cost airline such as Lion Air.

The traffic at UPG was slightly declined in 2014 due to two key factors. First, two airlines closed their operation; Batavia Airlines that served $14 \%$ of the total Indonesia domestic market and Merpati Airlines which specifically served route in the east Indonesia and had a base at UPG. Secondly, there were two volcano activities during 2014 which affected the traffic at UPG due to the closure of airport operations (AP I, 2014a). Nevertheless, Lion Air and Garuda Indonesia restore the traffic condition at UPG by adding more flights and serving $65 \%$ of total flights (Flightglobal, 2016). In overall, UPG historical data shows a positive trend of passenger growth over time.

\section{Short Term Forecast}

According to Wells (2004), time series method is used to forecast immediate future whilst assuming the behaviour that has persisted in the past will sustain. Components observed are trend, seasonal event and irregular phenomena.

Forecasting is distinguished to domestic, international and transit passenger. Transit passenger is important for UPG since many airlines make UPG as their hub to carry passenger from west to east Indonesia. Transit passenger will spending time at terminal and benefiting retails before continuing their flight. Accordingly, forecasting transit passenger is useful for the airport operator to estimate the need of retail area inside terminal building.

Forecasting international passenger was conducted collectively with domestic passengers because the annual international passenger at UPG was only around 150 thousand compare to 7.5 million domestic passengers. According to ACI (2011), forecasting small number of passengers is more extremely sensitive to strategies of a few airlines or the fluctuation of a limited number of markets. Currently there are ten international flights per week.

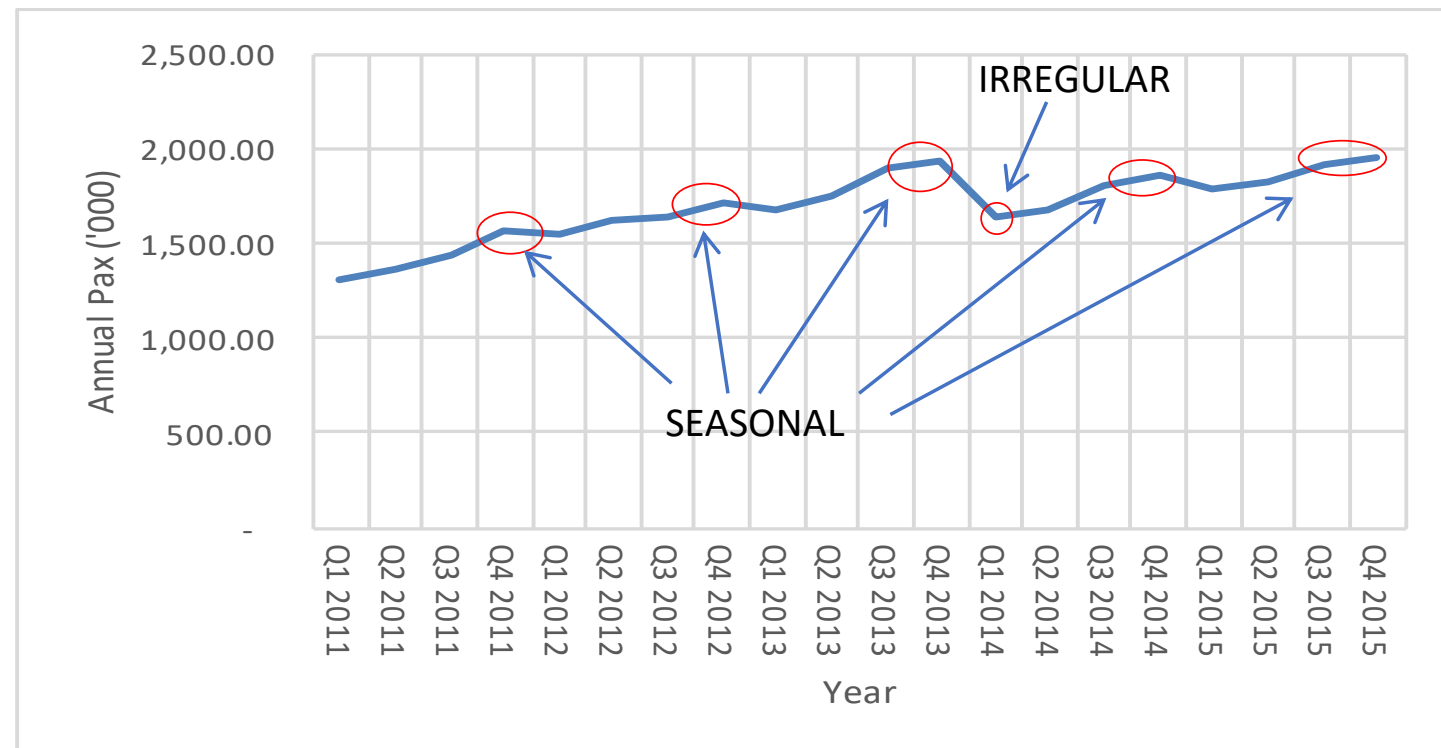

Figure 4. Five-Year Domestic-International

\section{Past Behaviour Analysis of Domestic- International Passenger Data}

It can be seen roughly from Figure 4 that there is a long-term upward trend, propensity to increase from Q3 and become maximum in Q4 followed by decreasing in Q1 every year. Urbanization is one of the major population problems in Indonesia. People from outside
Java Island tend to migrate, work and live in Java Island, which has the highest economic level (Saefuloh, 2013). However, during Holy month of Ramadan there is a tradition to go back to hometown celebrating Ramadan with big family. As a big Moslem country, the number of people using air transport was high 
during Ramadan period. From year 2011-2015, Holy month of Ramadan fell in Q3.

The increment of people travel at UPG reaches its peak in Q4 due to two reasons. First, in December Indonesia has stated 2 days off each for celebrating Christmas and New Year. There is a trend of people take their long-leave and have vacation with friends and relatives. Second, majority people in east Indonesia are Christians. Therefore like Ramadan, in Q4 many people travel back to their hometown to celebrate Christmas.

During January to March (Q1) people start to work as usual and have less travel. Business travelers are not many due to the beginning of company calendar. This condition makes a seasonal decreasing air traffic pattern from Q4 to Q1.

Two irregular phenomena happened in January 2014 when volcano activity of Mt.Kelud made the airport operator to close the airport for 4 days (AP I, 2014a) and Merpati Nusantara Airline announced bankruptcy (AP I, 2014b). Merpati used to have base at UPG and serve airports in border and remote area particularly in the eastern Indonesia.

Based on the explanation above, there are two time-series models suitable for the historical data forecasting with consideration of the existence of an upward trend, seasonal effect and irregular phenomenon. The candidate models are Holt-Winter and Decomposition Method. Forecasting the traffic for 2016 was made with the objective of minimizing square error, MSE. Afterward, check the goodness of fit through Mean Absolute Percentage Error (MAPE) and line figure.

Table 1. Goodness of Fit of Domestic-International Data

\begin{tabular}{|l|c|c|c|}
\hline & HW Additive & HW Multiplicative & Decomposition \\
\hline MAPE & $4.43 \%$ & $4.72 \%$ & $3.60 \%$ \\
\hline
\end{tabular}

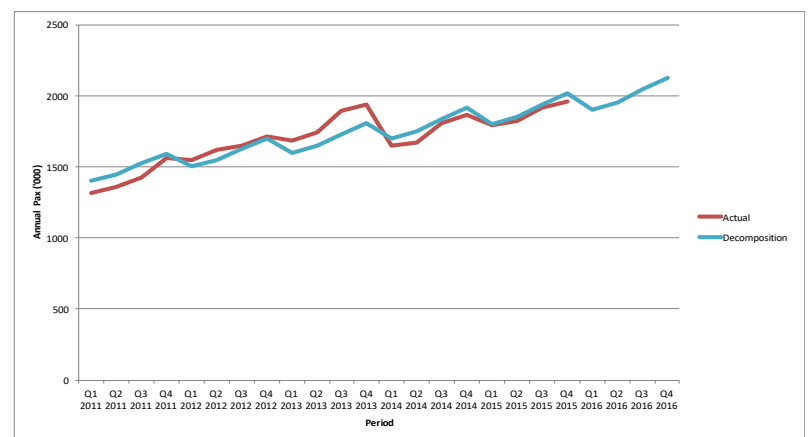

Figure 5. Line Graph of Domestic - International Data

As shown in Table 1 and Figure 5 above, Decomposition Method was chosen as the best model because it has the lowest MAPE and its graph shows the forecast line is close to the actual line.

The graph shows that in the future the upward trend and seasonal phenomenon still exist. It is reasonable due to the stability of current economic and political condition, strong national currency and low fuel price. This situation will strengthen airlines performance away from bankruptcy and maintain the purchase power of people. Furthermore, the forecast result is shown in Table 2.

Table 2. The Forecast of Domestic-International Passenger Data

\begin{tabular}{|l|c|c|c|c|}
\hline Forecast & Q1 2016 & Q2 2016 & Q 3 2016 & Q4 2016 \\
\hline Passengers & $1,898,426$ & $1,947,336$ & $2,043,222$ & $2,125,820$ \\
\hline
\end{tabular}
Past Behaviour Analysis of
Passenger Data

The characteristics of transit data are similar to the domestic-international data. Figure 6 indicates the existence of an upward trend, seasonal phenomenon and irregular situation within observation periods. The pattern of transit passengers follows the pattern of domestic-international passenger. The occurrence of seasonal and unusual events along graph is explained using domesticinternational analysis described in the previous part. The author is aware of the effect of transfer passengers for retails and terminal operation at UPG. However due to data limitation, transfer passengers are not involved in this research. 


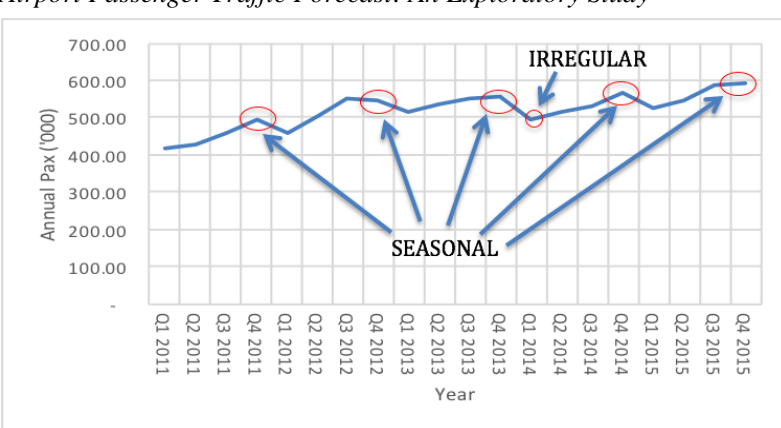

Figure 6. Five-Year Transit Data

Taking into account the existence of the upward trend, seasonal and irregular situation, thus Holt-Winter and Decomposition are selected as the suitable methods to forecast the immediate future. Followed the same instruction as mentioned in the previous part, Decomposition method is chosen as the best model since has the lowest MAPE and the closets line to actual data. Table 3 and Figure 7 present the comparison between methods.

Table 3. Goodness of Fit of Transit Data

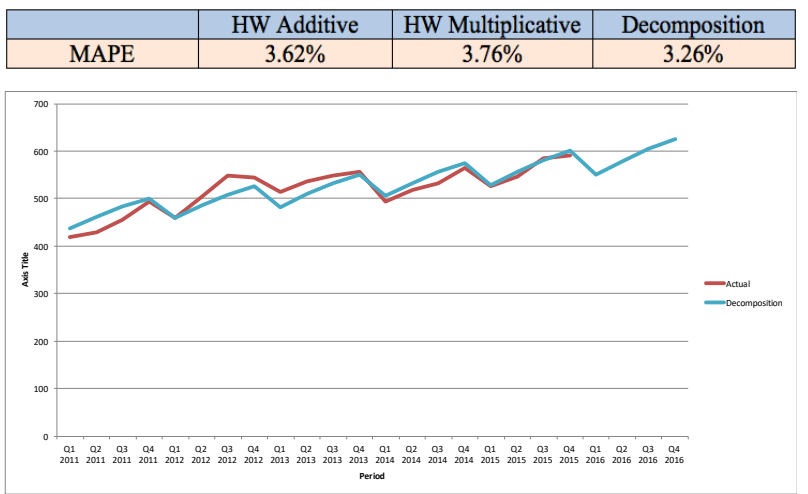

Figure 7. Line Graph of Transit Data

The graph shows that in the future the upward trend still exist and follow seasonal phenomenon. It is acceptable due to the mission of the elected President to develop the economic region of east Indonesia. Therefore it can be assumed that in the following years more people from east Indonesia travel to west Indonesia pass through UPG as their hub airport.

The forecast result using Decomposition is shown in Table 4.

Table 4. The Forecast of Transit Data

\begin{tabular}{|c|c|c|c|c|}
\hline Forecast & Q1 2016 & Q2 2016 & Q3 2016 & Q4 2016 \\
\hline Passengers & 550,211 & 579,626 & 605,139 & 624,797 \\
\hline
\end{tabular}

\section{Long Term Forecast}

According to IATA (2008), econometric model for air transport demand is explained through several explanatory variables such as ticket price, GDP, population and exchange rates. The spending ability of the market is affected by the volatility in the exchange rate (ACI, 2011). Moreover, ICAO (2006) states that the traffic generating factors such as population and GDP, fares and service levels have a measured impact on air transport.

Understanding the market is important to determine the driver of air transport demand. The air transport demand in Indonesia is largely driven by the economic and demographic factors. Rank 16th strongest economy in the world (World Bank, 2016) and large population wide spread to many islands are key success factors for aviation in Indonesia. Exchange rate is the main issue for Indonesian airlines for last decade.

\section{Explanatory variables}

National GDP, population and exchange rates are used as explanatory variables. However, GDP and population are highly correlated when used in one model (ICAO Forecasting Guidance, 2006). Therefore GDP per capita is used in this research. The data used is in current values to reduce the effects of inflation rates.

\section{Dummy Variables}

Two dummy variables are included in the model: Economic Recession (1998 and 2008) and Irregular phenomena (e.g. airport closure due to volcano activities and airline bankruptcy).

\section{Econometric Model}

$$
\begin{aligned}
& \begin{array}{l}
y= \\
y+b x_{1}+c x_{2}+d D u m m y_{1}+e D u m m y_{2}
\end{array} \\
& \mathrm{y}=\text { passenger } \\
& \mathrm{x}_{1}=\text { GDP per capita (constant local currency unit) (in } \\
& \quad \text { Rupiah) } \\
& \mathrm{x}_{2}=\text { exchange rate (1 USD to LCU) (in Rupiah) } \\
& \text { Dummy }=\text { Economic Recession (Yes }=1 ; \text { No }=0) \\
& \text { Dummy }
\end{aligned}
$$

\begin{tabular}{|c|c|c|c|c|c|}
\hline $\begin{array}{c}\text { Independent } \\
\text { Variables }\end{array}$ & $\begin{array}{c}\text { Estimated } \\
\text { Coefficient }\end{array}$ & $\mathrm{t}$ stat & $\mathrm{p}$-value & $\begin{array}{l}\text { Ho }(5 \%) \\
\text { rejected? }\end{array}$ & VIF \\
\hline Intercept & $-10,729,551$ & -20.954 & 0.000 & Yes & \\
\hline $\mathrm{x}_{1}$ & 0.573 & 24.542 & 0.000 & Yes & 1.596 \\
\hline $\mathrm{x}_{2}$ & 99.231 & 2.495 & 0.024 & Yes & 1.443 \\
\hline Dummy $_{1}$ & -354909.20 & -1.082 & 0.295 & No & 1.105 \\
\hline Dummy $_{2}$ & -648162.47 & -1.377 & 0.187 & No & 1.196 \\
\hline $\begin{array}{l}\text { R square } \\
\text { Adjusted R squ }\end{array}$ & & $\begin{array}{l}.985 \\
.981\end{array}$ & & & \\
\hline \multicolumn{6}{|c|}{ ANNOVA } \\
\hline $\begin{array}{l}\text { F stat } \\
\text { Significance F }\end{array}$ & & $\begin{array}{l}58.8127862 \\
.000\end{array}$ & & & \\
\hline
\end{tabular}

Table 5. Statistics Summary 
Table 5 shows that $\mathrm{F}$ stat is large and Significance F is very small, indicating that the model or the independent variables in the model are statistically significant to measure passenger number. $\mathrm{R}$ square is equal to 0.985 ; means the model explains $98.5 \%$ of the variability in passenger number. VIF values are below 10 indicating there is no multicollinearity between independent variables.

GDP per capita and exchange rate are statistically significant at 5\% significance level but none of the dummies are statistically significant. However, these two dummies are still included in the model because two reasons. First, economic recession is mainly affecting the people ability to travel as well as the financial performance of airlines. Second, irregular phenomenon such as the airline bankruptcy affects largely the airport activity. Moreover, Indonesia is located in the Ring of Fire therefore highly vulnerable to volcano activities where the aircraft engine is very sensitive to volcano ash.

\section{The Low, Medium and High Growth} Scenarios

According to World Bank (2015b), the future growth of Indonesia GDP is 5.3\% with low and high scenarios around 4.3-6.3\%. Indonesian Ministry of Finance has stated the future estimation of Rupiah is Rp13400/USD fluctuate within the range 13000-13900 with variation of $1.77 \%$ annually (MoF, 2015). Table 6 shows the future GDP and currency scenarios.

Table 6. Low-Medium-High Scenarios

\begin{tabular}{crrr}
\hline \multirow{2}{*}{ Year } & \multicolumn{3}{c}{ GDP } \\
\cline { 2 - 4 } & Low & Medium & High \\
\hline 2016 & $35,715,566$ & $36,057,997$ & $36,400,429$ \\
\hline 2017 & $37,251,336$ & $37,969,071$ & $38,693,656$ \\
\hline 2018 & $38,853,143$ & $39,981,432$ & $41,131,356$ \\
\hline 2019 & $40,523,828$ & $42,100,448$ & $43,722,631$ \\
\hline 2020 & $42,266,353$ & $44,331,772$ & $46,477,157$ \\
\hline
\end{tabular}

\begin{tabular}{crcr}
\hline \multirow{2}{*}{ Year } & \multicolumn{3}{c}{ Exchange Rates } \\
\cline { 2 - 4 } & Low & Medium & High \\
\hline 2016 & 13,000 & 13,400 & 13,900 \\
\hline 2017 & 13,230 & 13,637 & 14,146 \\
\hline 2018 & 13,464 & 13,879 & 14,396 \\
\hline 2019 & 13,703 & 14,124 & 14,651 \\
\hline 2020 & 13,945 & 14,374 & 14,911 \\
\hline
\end{tabular}

Table 7. Future Passenger Number

Year Low $\quad$ Medium $\quad$ High

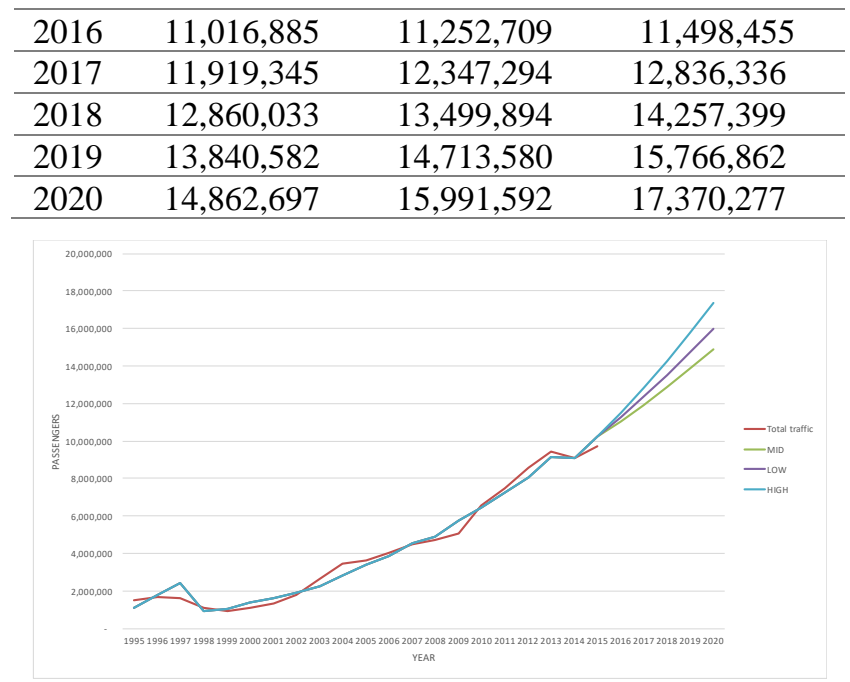

Figure 8. Future Passenger Growth

\section{Scenario Analysis}

As can be seen in Table 7 and Figure 8, total passengers increase at certain level depend on the assumptions. However each scenario has risks and opportunities which explained in Table 8 below.

\section{Table 8. Scenario Analysis}

\begin{tabular}{|c|c|c|}
\hline Growth & Risk & Opportunity \\
\hline Low & $\begin{array}{ll}\text { - } & \text { Failed to } \\
\text { gain benefit } \\
\text { from } \\
\text { ASAM } \\
\text { - } \\
\text { Decreasing } \\
\text { on } \\
\text { utilization } \\
\text { of airport } \\
\text { facility } \\
\text { Less non- } \\
\text { aeronautical } \\
\text { revenue }\end{array}$ & $\begin{array}{l}\text { - Less congestion } \\
\text { at the airport } \\
\text { - Good surface } \\
\text { access } \\
\text { - Maintaining the } \\
\text { level of } \\
\text { passenger } \\
\text { satisfaction } \\
\text { No need to } \\
\text { develop airport } \\
\text { infrastructure } \\
\text { immediately }\end{array}$ \\
\hline Medium & $\begin{array}{ll}\text { - } & \text { Airport } \\
\text { capacity } \\
\text { constraint } \\
\text { - } \quad \text { Regional } \\
\text { economic is } \\
\text { developed } \\
\text { at moderate } \\
\text { level }\end{array}$ & $\begin{array}{ll}\text { - } & \text { Expansion of } \\
\text { LCCs } \\
\text { - } & \text { Took benefits } \\
\text { from ASAM } \\
\text { - New routes } \\
\text { especially } \\
\text { international } \\
\text { routes (ASEAN } \\
\text { region) } \\
\text { Optimizing } \\
\text { airport facilities } \\
\text { - Non aeronautical } \\
\text { revenue }\end{array}$ \\
\hline High & $\begin{array}{ll}\text { - } & \text { Airport } \\
\text { capacity } \\
\text { constraint } \\
\text { - } \quad \text { Surface } \\
\text { Access } \\
\text { problem } \\
\text { - } \quad \text { Terminal } \\
\text { congestion } \\
\text { - } \quad \text { Poor } \\
\text { passenger } \\
\text { experience }\end{array}$ & $\begin{array}{ll}\text { - } & \text { Took benefits } \\
\text { from ASAM } \\
\text { - } & \text { New routes both } \\
\text { domestic and } \\
\text { international } \\
\text { routes (ASEAN } \\
\text { region) } \\
\text { Non aeronautical } \\
\text { revenue } \\
\text { Fast regional } \\
\text { economic } \\
\text { development }\end{array}$ \\
\hline
\end{tabular}




\section{Backtesting Validation}

Evaluation of the forecast model is done by using backtesting method. Table 9 presents comparison between actual annual passenger number (AP I, 2020) and calculated number using selected econometric formula by applying real GDP per capita and exchange rate during 2016-2018 derived from World Bank (2020).

It is shown that the selected econometric model successfully foretells annual passenger movement with the estimation average deviation around $0.5 \%$.

Table 9. Projected vs Actual Passenger Number

\begin{tabular}{cccc}
\hline Year & Actual GDP & $\begin{array}{c}\text { Actual } \\
\text { Exchange Rate }\end{array}$ & $\begin{array}{c}\text { Projected } \\
\text { Number }\end{array}$ \\
\hline 2016 & $36,071,348$ & 13,308 & $11,251,258$ \\
\hline 2017 & $37,457,329$ & 13,381 & $12,052,287$ \\
\hline 2018 & $38,949,651$ & 14,237 & $12,991,981$ \\
\hline
\end{tabular}

\begin{tabular}{cccc}
\hline Year & $\begin{array}{c}\text { Projected } \\
\text { Number }\end{array}$ & $\begin{array}{c}\text { Actual } \\
\text { Number }\end{array}$ & $\begin{array}{c}\text { Estimation } \\
\text { Deviation }\end{array}$ \\
\hline 2016 & $11,251,258$ & $10,756,737$ & $-4,60 \%$ \\
\hline 2017 & $12,052,287$ & $12,293,962$ & $1,97 \%$ \\
\hline 2018 & $12,991,981$ & $13,537,469$ & $4,03 \%$ \\
\hline \multicolumn{3}{c}{ Average } & $0.47 \%$ \\
\hline
\end{tabular}

Route Expansion

ASEAN Single Aviation Market (ASAM) is believed to have an impact to the growth of international flights particularly at UPG. Currently, only few numbers of international passengers have flight to UPG. According to Indonesia Statistics Bureau (2015), the Philippine are the third biggest ASEAN tourist in Indonesia. UPG as the closest airport to Philippine has an advantage to open direct route to Ninoy Aquino International Airport in Manila. Lion Air, which currently has no flights to Manila, is persuaded to serve this route in order to strengthening their market in ASEAN region and optimize their new fleets.

\section{CONCLUSION}

This chapter summarizes conclusion based on the analyses described previously:

1. Forecasting transit passenger should be conducted separately from other traffic since UPG is an important hub airport connecting passenger from west to east Indonesia.

2. Due to relatively small number of international traffic, forecasting international passenger was conducted collectively with domestic passengers as ACI indicates that forecasting small number of passengers is more extremely sensitive to strategies of a few airlines or the fluctuation of a limited number of markets.

3. Decomposition Method is selected as the best model compare to Holt-Winter to undertake short-term forecasting at UPG with consideration of the existence of an upward trend, seasonal effect and irregular phenomenon.

4. Econometric model is opted to conduct long-term forecast. GDP per capita and exchange rates are selected as explanatory variables including two dummy variables: Economic Recession and Irregular phenomena.

5. UPG needs to consider risks and opportunities for the forthcoming traffic under low, medium and high growth scenarios.

6. Backtesting method validates that even though the econometric model is built under 1995-2015 data but the selected model successfully foretells annual passenger movement 2016-2018 with the estimation average deviation around $0.5 \%$.

\section{REFERENCES}

ACI (2011). ACI Airport Traffic Forecasting Manual: A practical guide addressing best practices. Available at: http://www.aci.aero/Media/aci/file/Publ ications

2011/ACI_Airport_Traffic_Forecastin g_Manual_2011.pdf (accessed 10 February 2016).

Airbus (2013). Lion Air Orders 234 A320 Family Aircraft. Available at: http:// www.airbus.com/presscentre/pressrelea ses/press-release-detail/detail/lion-airorders-234-a320-family-aircraft/ (accessed 10 February 2016).

AP I (2011). Sultan Hasanuddin International Airport: The History. Available at: 
http://hasanuddin-airport.co.id/sejarah (accessed 10 February 2016).

AP I (2014a). Eruption of Mt. Kelud affected airport activity at Sultan Hasanuddin International Airport. Available at: http://hasanuddin-airport.co.id/detail/ berita/erupsi-gunung-kelud-berdampakterhadap-penerbangan-di-bandarainternasional-sultan-hasanuddinmakassar (accessed 11 February 2016).

AP I (2014b). Merpati Announced Bankruptcy. Available at: http://hasanuddinairport.co.id/detail/berita/merpatihengkang-angkasa-pura-airports-tenang (accessed 12 February 2016).

AP I (2016). Sultan Hasanuddin International Airport: Traffic Data Report. (Unpublished Document).

AP I (2020). Sultan Hasanuddin International Airport: Traffic Data Report. (Unpublished Document).

Asian Development Bank (2015). Asian Development Bank and Indonesia: Fact Sheet. Available at: http://www.adb.org/publications/indone sia-fact-sheet (accessed 11 February 2016).

Boeing (2011). Lion Air Announce Historic Commitment for up to $380737 \mathrm{~s}$. Available at: http://boeing.mediaroom.com/index.ph $\mathrm{p}$ ? $=20295 \&$ item $=2036 \quad$ (accessed 10 February 2016).

Boeing (2014). World Air Cargo Forecast 2014-2015. Available at: http://www.boeing.com/resources/boein gdotcom/commercial/about-ourmarket/cargo-market-detailwacf/downloadreport/assets/pdfs/wacf.pdf (accessed 11 February 2016).

CAPA (2016). Makassar Sultan Hasanuddin Airport. Available at: http://centreforaviation.com/profiles/air ports/makassar-sultan-hasanuddinairport-upg (accessed 13 February 2016).

Christoffersen, P. (2003). Backtesting ValueAt-Risk. Montréal: Centre interuniversitaire de recherche en analyse des organisations.
Flightglobal (2014). Angkasa Pura I outlines expansion of Makassar airport. Available at: http://dashboard.flightglobal.com/app/\# /articles/396617?context=airport (accessed 12 February 2016).

Flightglobal (2016). Makassar-Sultan Hasanuddin Airport. Available at: http://dashboard.flightglobal.com/app/p rofiles/\#/airport/airlines/-14276 (accessed 11 February 2016).

IATA (2008). Air Travel Demand. Available at: https://www.iata.org/whatwedo/ documents/economics/air_travel_dema nd.pdf (accessed 12 February 2016).

ICAO (2006). Manual on Air Traffic Forecasting. Available at: http://www.icao. int/MID/Documents/2014/Aviation\%20 Data\%20Analyses\%20Seminar/8991_F orecasting_en.pdf (accessed 10 February 2016).

MoF (2015). Indonesia Ministry of Finance: Notes of Financial Statement Year 2016. Available at: http://www.anggaran.depkeu.go.id/dja/ acontent/NKRAPBN 2016. pdf (accessed 12 February 2016).

MoT (2013). Indonesia Ministry of Transport Decree No.69 Year 2013 on National Airport Hierarchy. Available at: http://hubud.dephub.go.id/?id/kep men/index/filter:tahun,2013 (accessed 11 February 2016).

Saefuloh, A.H. (2013). Urbanization, Job Opportunity \& Integrated Economic Policy. Jakarta: Indonesia House of Parliament.

Saraswati, B. \& Hanaoka, S. (2013). Aviation Policy in Indonesia and Its Relation to ASEAN Single Aviation Market. Available at: https://www.jstage.jst.go.jp/ article/easts/10/0/10_2161/_pdf (accessed 11 February 2016).

Suryan, V. (2017). Econometric forecasting models for air traffic passenger of indonesia. In Journal of the Civil Engineering Forum (Vol. 3, No. 1, pp. 33-44). 
Wells, A.T. \& Young, S.B. (2004). Airport Planning \& Management, $5^{\text {th }} \mathrm{ed}$. New York: McGraw-Hill.

World Bank (2015a). GDP Ranking. Available at: http://data.worldbank.org/ datacatalog/GDP-ranking-table (accessed 14 February 2016).

World Bank (2015b). Global Economic Prospects. Available at: http://www. worldbank.org/en/publication/globaleconomic-prospects/data?region=EAP (accessed 13 February 2016).
World Bank (2016). World Development Indicators. Available at: http://data bank.worldbank.org/data/reports.aspx?I $\underline{\mathrm{d}=5 \mathrm{e} 65 \mathrm{e} 215 \& \text { Report_Name }=\text { ASEAN\# }}$ (accessed 11 February 2016)

World Bank (2020). Indonesia | Data. Available at: https://data.worldbank.org/country/indo nesia (accessed 17 November 2020). 